\title{
MINERALOGY, ORIGIN AND COMMERCIAL VALUE OF THE ZEOLITE-RICH TUFFS IN THE PETROTA-PENTALOFOS AREA, EVROS COUNTY, GREECE
}

\author{
M. G. Stamatakis *, A. Hall **, U. Lutat *** and J. N. Walsh **
}

\begin{abstract}
The zeolite-rich tuffs of the Petrota-Pentalofos area were deposited in the Orestias Basin during the Eocene. They are up to $100 \mathrm{~m}$ thick and extend more than $15 \mathrm{Km}$ in a long axis. Most of the outcrops consist of frequent alternations of very fine grained tuff with pumice and lapilli tuffs, the latter containing detrital fragments of the Mesozoic substrate of the basin.

X-ray Diffraction, Scanning Electron Microscopy and light microscopy analysis on quarry and borehole samples has shown that the tuffs are composed mainly of clinoptilolite and minor cristobalite, with a small proportion of detrital constituents (quartz, mica-schist) and pyrogenic crystals (feldspars, quartz, biotite). Minor amounts of mordenite randomly occur in some of the northern outcrops, closer to the occurrences of lava. ICP-AES chemical analysis of the tuffs gives evidence that the original magmas were of quartz-latite composition.

The tuffs rest on pre-Cenozoic metamorphic basement and pass gradationally upwards into sandstone and limestone. Evidence is given for deposition of the tuffs in a supra to infra-littoral environment. The zeolitic tuffs originated as epiclastic volcanic sediments, transported by water from the source of the eruption. The transformation of the volcanic glass of the tuffs to zeolite and cristobalite has taken place by meteoric waters in an open hydrological system existed during the Tertiary. The zeolitic rocks are currently being exploited as an animal feed supplement.
\end{abstract}

Key words: Zeolite, Tuff, Clinoptilolite, Mordenite, Greece.

\section{RESUMEN}

Las tobas ricas en ceolitas del área de Petrota-Pentalofos se depositaron en la cuenca de Orestias durante el Eoceno. Alcanzan $100 \mathrm{~m}$ de potencia y superan los $15 \mathrm{~km}$ de extensión longitudinal. La mayoría de los afloramientos consisten en alternancias de toba de grano muy fino y toba de pómez y lapilli con fragmentos detríticos del sustrato Mesozoico de la cuenca.

Análisis por difracción de rayos $\mathrm{X}$, microscopía electrónica de barrido y microscopía óptica en muestras de mano y de sondeos demuestran que las tobas están fundamentalmente compuestas por clinoptilolita y cristobalita con una pequeña proporción de constituyentes detríticos (cuarzo, esquistos micáceos) y minerales pirogénicos (feldespatos, cuarzo, biotita). Pequeñas cantidades de mordenita aparecen ocasionalmente en algunos de los afloramientos del norte cercanos a lavas. Análisis químicos de las tobas mediante ICP-AES indican que los magmas originales eran de composición cuarzo-latítica.

Las tobas se apoyan sobre un basamento metamórfico pre-Cenozoico y gradan hacia techo a arenisca y marga. Hay evidencias de que las tobas se depositaron en un ambiente supra- a intra-litoral. Las tobas ceolíticas se originaron como sedimentos volcánicos epiclásticos, transportados por el agua desde la fuerza eruptiva. La transformación del vidrio volcánico de las tobas en ceolita y cristobalita fue causada por aguas meteóricas en sistema abierto durante el Terciario. Las rocas ceolíticas se explotan en la actualidad para suplemento alimenticio de animales.

Palabras claves: Ceolitz, Tobas, Clinoptilolita, Mordenita, Grecia.

\footnotetext{
* National University of Athens, Department of Geology, Panepistimiopolis, Ano Ilissia 157 84, Athens, Greece.

** Royal Holloway, University of London, Egham, Surrey, TW20 0EX, UK.

*** Silver \& Baryte Ores Mining Company, Amerikis $21 \mathrm{~A}$, Athens, Greece.
} 


\section{Introduction}

In Evros County, northern Greece, there are zeolite deposits of both sedimentary and hydrothermal type (Kosiaris et al., 1987; Skarpelis et al., 1987; Marandos et al., 1989; Tsolis-Katagas and Katagas, 1990, Koutles et al., 1995; Stamatakis et al., 1996). The hydrothermally formed zeolites are associated with mixed sulphide and gold mineralization and occur only in small amounts. In contrast, large sedimentary zeolite deposits occur in both the Alexandroupolis and Orestias Tertiary basins, Evros County and are characterised by the abundance of clinoptilolite and/or mordenite (Stamatakis et al., 1996). Those in the Orestias basin are derived from the alteration of Eocene pyroclastic rocks; the compositions of the magmas in this region range from basaltic andesite to rhyolite and trachyte (Andronopoulos, 1977; Kosiaris et al., 1987; Eleftheriadis et al., 1989).

The Pentalofos-Petrota area is situated in the north-western part of the Orestias basin and lies on the eastern edge of the Rhodope metamorphic massif. In the western part of the area (fig. 1), Eocene sediments and volcanic rocks lie directly on the preCenozoic metamorphic basement and dip in a generally north-eastward direction, although locally they show steep dips and faulting due to intrabasinal tectonics. Towards the east the Eocene is covered unconformably by clastic Neogene sediments in the central part of the basin (Andronopoulos, 1977; Noussinanos, 1991).

Zeolitized pyroclastic rocks have been located in the NW part of the Orestias basin, in at least six major outcrops. All six outcrops fall within the Pentalofon Sequence of Andronopoulos (1978a), and correspond approximately to his «Cohesive gritbreccia». They lie in a belt extending for $15 \mathrm{~km}$ from NW to SE (fig. 1). The southernmost edge of the formation occurs at the village Ammovounon, where the tuffs gradually pass into sandstone (Andronopoulos, 1978b). However, similar tuffs are more widely developed in the Bulgarian territory to the west associated with acid and intermediate lava eruptions (Yanev \& Bardintzeff, 1997). The subject of this paper is to describe the extent and composition of these zeolite tuff outcrops and to discuss their origin and genetic relationship.

\section{Analytical techniques}

The mineralogy of approximately 250 samples was determined by X-ray diffraction using a Philips X'Pert-APD computercontrolled diffractometer equipped with a monochromator and APD analytical software. The rock powders were prepared in cavity mounts, levelled off by knife edge without pressing, in

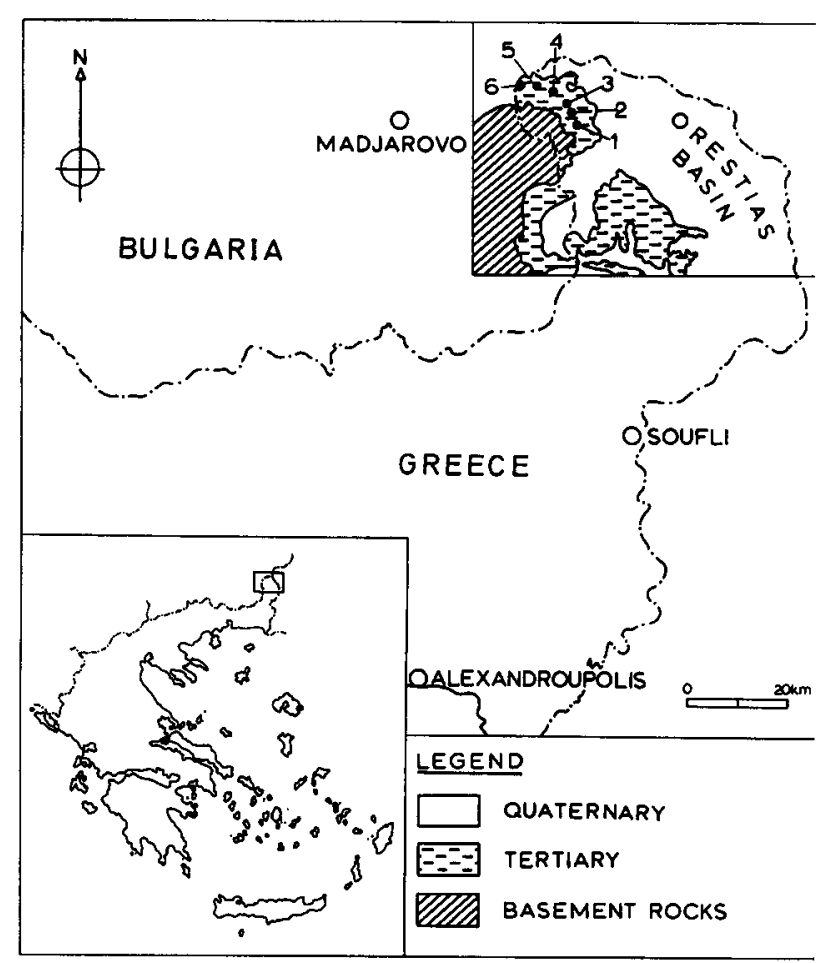

Fig. 1.-Map showing the studied areas and the sites of the zeolite deposits.

order to minimise preferred orientation. Selected samples were also subjected to repeated treatment with hot hydrochloric acid to remove the zeolite, enabling better identification of the nonzeolitic components.

External standards for X-ray diffraction were made up from mixtures of pure minerals. In the case of clinoptilolite, pure material of an appropriate composition was not available for making standards, so all measurements were made against a natural sample of clinoptilolite-rich, feldspar-poor rock from Pentalofos whose zeolite content had previously been determined by thermogravimetric analysis. This sample contained $9.6 \%$ of zeolitic water, equivalent to $71 \%$ of clinoptilolite by weight. Chemical analyses were made by ICP-AES. For $\mathrm{SiO}_{2}$, $\mathrm{Al}_{2} \mathrm{O}_{3}$ and zirconium, samples were decomposed by fusion with $\mathrm{KOH}$ in nickel crucibles and brought into solution in dilute $\mathrm{HNO}_{3}$. For other major and trace elements, samples were decomposed by a $\mathrm{HF}-\mathrm{HClO}_{4}$ treatment in Teflon crucibles and brought into solution in dilute hydrochloric acid. Loss on ignition was determined by heating at $1100^{\circ} \mathrm{C}$ for 2 hours. SEM analysis were performed in the USGS laboratories at Menlo Park, California.

\section{Geology of the Zeolitic Tuff Occurrences}

The volcanic rocks, including the zeolitic tuffs, occur in a NW-SE belt extending through the villages of Petrota (site n. ${ }^{\circ}$ ) and Pentalofos (site n. ${ }^{\circ}$ 1). In the hilly country close to the Bulgarian border the exposure is good, but further to the SE exposure is mainly confined to small quarries, and in a large part of this area the Eocene is mainly confined to small quarries, and in a large part of this area the 


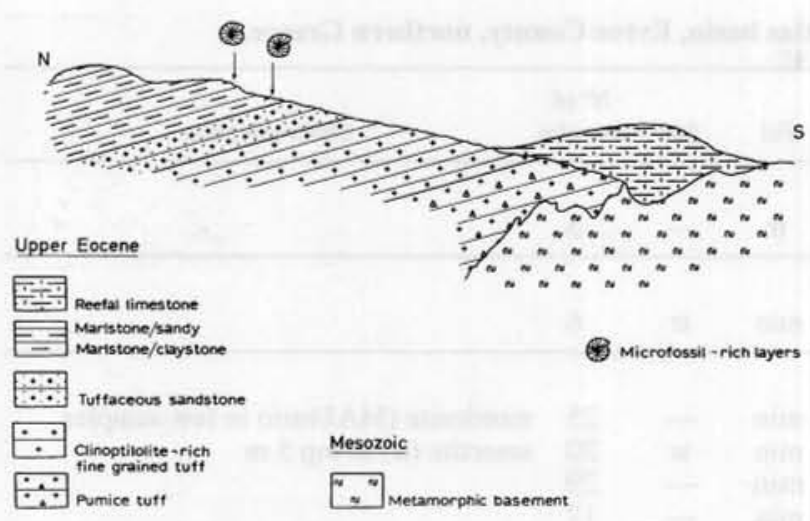

Fig. 2.- Schematic representation of the stratigraphy in the Pentalofos-Twin Hills-Palestra areas, Orestias Basin.

Eocene is concealed by overlapping Quaternary deposits. Within the volcanic belt, actual lava are seen at only a few places in the Petrota area; further to the south-east the volcanic succession consists entirely of tuffs.

West of the volcanic belt, the Paleogene succession consists of conglomerate and sandstone of lacustrine or brackish water facies with occasional thin intercalations of lignite. Both these continental deposits and the pyroclastic rocks were deposited directly onto the metamorphic basement. As shown by surface outcrops and borehole data, the tuffaceous rocks of the Petrota-Pentalofos area are conformably overlain by marlstone and siltstone. Small isolated outliers of marine limestone of Upper Eocene age discordantly cover either the tuffs or the marlstone or sometimes the metamorphic basement (fig. 2) (Andronopoulos, 1978a\&b).

The main outcrops of the tuff are as follows (fig. 1):

(1) Pentalofos. Poorly to intensely zeolitized tuffs occur in an area of about $0.5 \mathrm{~km}^{2}$, surrounded by grey-brownish claystone and marlstone. Rarely, the metamorphic basement occur in the nearby stream gorges, covered by green-whitish pumice tuff that host large clasts of the basement rocks. The tuffaceous rocks of the area can be divided into three lithological divisions. The uppermost division is represented by a greyish-white fine-grained tuff, the middle division is represented by very fine-grained green tuff, and the lowermost division is composed of green-whitish lapilli tuff that hosts many heterogeneous clasts of various sizes (figs. 2 \& 3 ).

(2) Twin Hills. A small outcrop $\left(0.05 \mathrm{~km}^{2}\right)$ of zeolitic tuff rests on metamorphic basement (chlorite-mica-schist). This outcrop is the most severely affected by tectonic activity of the five, and dips partly gently to the east, and partly with a high angle to the south east.

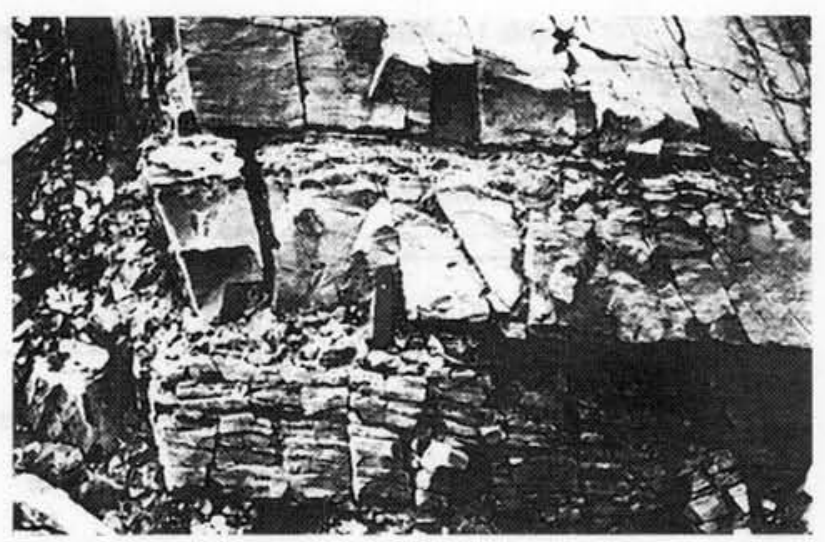

Fig. 3.-Zeolite tuff outcrop in Pentalofos quarry. Note the soft, smectite-bearing intervals.

Most of the marlstone layers that exhibit turbiditic character, are fossil-rich, containing benthic and plangtonic foraminifers, as well as small tube-like bivalves of shallow marine origin (Teredo $S p$.). Rare gastropods also occur. Some of the foraminifers have been transported via small channels for short distances. In addition, scattered, recrystallized sponge and echinoid spicules are commonly present. Notably, sponge spicules along with other siliceous tests are also referred from the Oligocene zeolitic tuffs of the nearby eastern Bulgaria (Djurova and Aleksiev 1990). The fauna of the bivalves is indicative for the existence of turbidity currents in the basin, which cause a suspension of the nutrients that are requisite for their growth. The shell of the bivalves is recrystallized containing silica replacing calcite. A local accumulation of microfossils commonly occurs in some maristone beds, due to the low sedimentation rates existed after the deposition of the tuffs. Additionally, all micro-fossils detected define an inner infra-littoral environment of deposition (maximum depth of about $80 \mathrm{~m}$ ). The zeolitized tuff grades into marlstone that encloses thin films of tuffaceous material, and finally to marlstone-siltstone that exhibits turbiditic character.

As it is resulted by the XRD analysis on representative tuff samples, the zeolite tuff is very rich in clinoptilolite (table 1).

(3) Palestra. An inlier $\left(>0.5 \mathrm{~km}^{2}\right)$ of zeolitic tuffs is surrounded by Quaternary sands and clays. The tuffs here dip generally to the east at approximately $10-15^{\circ}$. At Palestra, massively bedded coarser units (beds $>30 \mathrm{~cm}$ thick) are interbedded with thinly bedded finer units (beds $<10 \mathrm{~cm}$ thick), and in some beds there is a gradation from fine into coarse upwards (fig. 4). Channel-fill structures and lenses up to $1 \mathrm{~m}$ of sand and gravel are visible in a quarry here, and similar material is present in the borehole Pal-G1. The lenses of loose dark brown to 
Table 1.-Mineralogy of zeolitic tuffs of Orestias basin, Evros County, northern Greece.

\begin{tabular}{|c|c|c|c|c|c|c|c|}
\hline & $\mathrm{Cpt}$ & Crist & $\mathrm{Qz}$ & Fel & Mc & $\begin{array}{l}\text { № of } \\
\text { samples }\end{array}$ & Other minerals \\
\hline 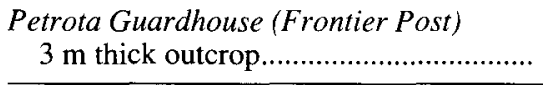 & MAJ & $\min$ & $\min$ & $\mathrm{tr}$ & - & 3 & \\
\hline 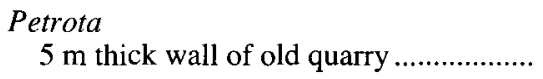 & MAJ & $\min$ & $\min$ & $\min$ & $\operatorname{tr}$ & 6 & \\
\hline $\begin{array}{l}\text { Petrota Paleochorafa } \\
\quad 15 \mathrm{~m} \text { thick wall of active quarry ............. } \\
\text { borehole PetG1 }(0-25 \mathrm{~m}) \ldots \ldots \ldots \ldots \ldots \ldots \ldots . . . \\
\text { borehole PetG1 }(25-60 \mathrm{~m}) \ldots \ldots \ldots \ldots \ldots \\
\text { borehole PetG1 }(60-97 \mathrm{~m}) \ldots \ldots \ldots \ldots \ldots \ldots \ldots \ldots\end{array}$ & $\begin{array}{l}\text { MAJ } \\
\text { MAJ } \\
\text { MAJ } \\
\text { MAJ }\end{array}$ & $\begin{array}{l}\min \\
\min \\
\min \\
\min \end{array}$ & $\begin{array}{c}\min / \operatorname{tr} \\
\min \\
\min \end{array}$ & $\begin{array}{l}\min \\
\min \\
\min \\
\min \end{array}$ & $\overline{\operatorname{tr}}$ & $\begin{array}{l}25 \\
20 \\
29 \\
17\end{array}$ & $\begin{array}{l}\text { mordenite (MAJ/min) in few samples } \\
\text { smectite (tr) in top } 5 \mathrm{~m}\end{array}$ \\
\hline 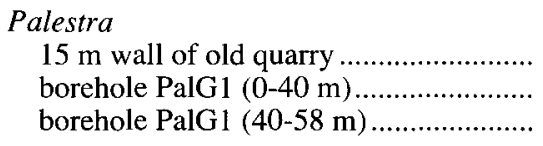 & $\begin{array}{l}\text { MAJ } \\
\text { MAJ } \\
\text { MAJ }\end{array}$ & $\begin{array}{l}\min \\
\min \\
\min \end{array}$ & $\underset{\operatorname{tr}}{\min / \operatorname{tr}}$ & $\begin{array}{l}\min \\
\min \\
\min \end{array}$ & $\frac{\operatorname{tr}}{\operatorname{tr}}$ & $\begin{array}{r}9 \\
32 \\
14\end{array}$ & \\
\hline 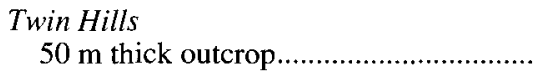 & MAJ & $\min / \mathrm{tr}$ & $\min$ & $\mathrm{min} / \mathrm{tr}$ & $\operatorname{tr}$ & 14 & \\
\hline 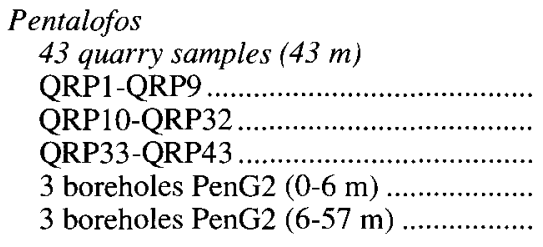 & $\begin{array}{l}\min \\
\text { MAJ } \\
\bmod \\
\bmod \\
\text { MAJ }\end{array}$ & $\begin{array}{l}\min \\
\min \\
\min \\
\min \\
\min \end{array}$ & $\begin{array}{l}\mathrm{MAJ} \\
\mathrm{min} / \mathrm{tr} \\
\mathrm{MAJ} \\
\mathrm{min} \\
\mathrm{min} / \mathrm{tr}\end{array}$ & $\begin{array}{l}\text { MAJ } \\
\min \\
\bmod \\
\min \\
\min \end{array}$ & $\begin{array}{c}\operatorname{tr} \\
\operatorname{tr} \\
\operatorname{tr} \\
\min \\
\operatorname{tr}\end{array}$ & $\begin{array}{r}9 \\
23 \\
11 \\
6 \\
50\end{array}$ & $\begin{array}{l}\text { smectite }(\mathrm{tr}) \text { in some specimens } \\
\text { smectite }(\mathrm{min} / \mathrm{tr})\end{array}$ \\
\hline
\end{tabular}

Explanatory notes: MAJ = major component $(40-90 \%)$, mod $=$ medium component $(20-40 \%), \min =$ minor component $(5-10 \%)$, $\mathrm{tr}=$ trace component $(<5 \%) . \mathrm{Cpt}=$ clinoptilolite, Crist $=$ cristobalite, $\mathrm{Qz}=$ quartz, Fel $=$ feldspar, $\mathrm{Mc}=$ mica.

black sand and gravel are exclusively composed of fragments of metamorphic rocks such as gneiss, schist and quartzite. They have a north-south long axis, laterally thinning in the tuffaceous host rock.

Northeast-Southwest oriented faults with throws of some $10 \mathrm{~m}$ are visible in the front of the existing quarry. As a result, the northernmost Palestra zeolite deposit contains only the lowermost part of the succession, whereas the southernmost deposit is more complete.

(4) Petrota. $1 \mathrm{~km}$ south-east of Petrota village there exist several small abandoned quarries in an area of about $0.5 \mathrm{~km}^{2}$, developed on the zeolitic tuffs. It represents the northern extension of Palestra tuff, having the same sedimentological features and mineralogical composition.

(5) Petrota Paleochorafa. Two outcrops of about $0.3 \mathrm{~km}^{2}$ of pumice and lapilli tuff occur NE of Petrota village in close proximity to basement rocks. The are associated with claystone, volcanic conglomerates and lava flows.

(6) Petrota Guardhouse. There are small outcrops of less than $0.3 \mathrm{~km}^{2}$ of tuffs surrounded by volcanic breccio-conglomerate and volcanic domes. In the Petrota Guardhouse and Petrota-Paleochorafa areas, pink or pale green lava is irregularly present adjacent to the main tuff outcrops. The groundmass of these lavas is not zeolitized but is highly silicified and rich in cristobalite.

At all these outcrops the tuffaceous material varies in grain size; coarse volcanic conglomerates and lapilli tuff predominate in the north (Petrota), and fine-grained ash tuff predominates in the south (Pentalofos). Pumice tuff intervals occur frequently in all outcrops but are more abundant at the lowermost stratigraphic levels. In general, the colour of all the tuffs is white (coarser tuffs) or pale green (finer tuffs), but the greenish tuffs usually weather to a creamy colour.

The age of these tuffs and marlstone has been determined as Upper Eocene (Andronopoulos, 1977 \& 1978a). From field observations, channel sampling and boreholes measurements, the maximum thickness of the tuff is some $60 \mathrm{~m}$ in the southernmost outcrop, increasing to some $90 \mathrm{~m}$ in the north, near Petrota.

At Pentalofos, Palestra and Petrota, the tuff is partially exploited by the local authorities to use as road covering during wet periods. 


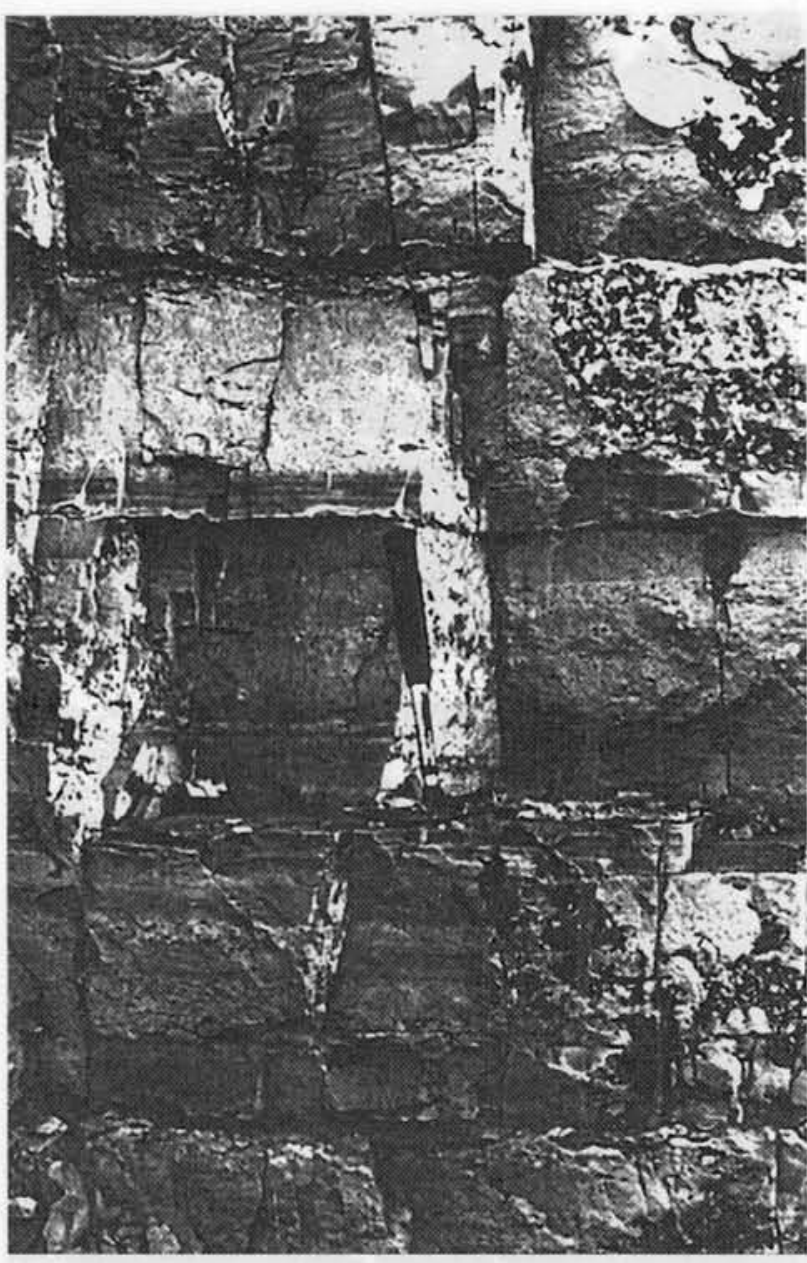

Fig. 4.-Turbiditic layers from Palestra quarry. Note the finegrained zeolite tuff at the head of the hammer and the coarse tuff at its handle. A small conglomerate horizon with channel fill structure is shown at the top.

\section{Petrography}

\section{The parental lava}

Lavas which are believed to represent the parental material of the zeolitic rocks occur at Petrota, as small outcrops and as fragments in volcanic breccias. They are latites, and consist of plagioclase and $\mathrm{K}$-feldspar phenocrysts with minor biotite in a cryptocrystalline groundmass, identified by X-ray diffraction as a mixture of cristobalite and $\mathrm{K}$-feldspar. The lavas vary in colour from pale green to pink.

\section{The zeolitic tuffs}

There are wide variations in grain size, but the main petrographic features of the tuffs are the same at all the localities. Typically, a coarse-grained tuff contains from $10-40 \%$ of crystals, $60-90 \%$ of (devitrified) glassy matrix, and $0-20 \%$ of lithic clasts. Pumice clasts are present in some tuffs but not others.

The crystals are mostly feldspars (plagioclase and sanidine), quartz and biotite, and less commonly muscovite. In a coarse tuff the size of the crystals normally ranges up to about $0.5 \mathrm{~mm}$. Crystals are often broken, and in the case of micas severely bent. However, euhedral crystals are not uncommon, and rounded crystals also occur. The feldspars and biotite are normally fresh, except in outcrop specimens that show obvious weathering. A minority of biotite crystals are chloritized. The mineralogical composition of the volcanic (i.e. pyrogenic) material of the tuffs does not vary appreciably across the belt.

The matrix typically shows the outlines of cuspate glass shards, with concave margins representing the former walls of gas bubbles (Plate 1; A, B).

Some intact bubbles are preserved. On the whole the glass shards are not flattened and intact bubbles are circular rather than oval in cross section. The terminations of the cusps are broken rather than streaked out. The maximum size of the recognisable glass shards is generally similar to that of the relict crystals (Plate 1; D, E).

Recognisable pumice fragments include some that are flattened and some that are not. The flattened ones are not all oriented in the plane of the bedding and they are sometimes mixed with detrital (non-volcanic) material. Non-flattened pumice fragments include some which contain microscopic pipe vesicles.

The microcrystalline material which constitutes the devitrification product of the glass shards is anisotropic, but in most cases individual crystals can not be distinguished by optical microscopy. However, in some of the larger glass shards, the secondary mineral (i.e. zeolite) is seen to form radiating crystal aggregates which have nucleated from the walls of the shard (figs. $5 \& 6$ ). X-ray diffraction shows that the microcrystalline material is a mixture of secondary minerals, mainly clinoptilolite but also cristobalite and in a few cases mordenite or smectite. A small proportion of the K-feldspar may also be secondary, since it occurs in microscopic veinlets cutting the tuffs at Pentalofos, and secondary K-feldspar of adularia habit has been detected at Petrota by SEM examination (Kirov et al., 1990); however the majority of the $\mathrm{K}$-feldspar is primary, as seen from the sanidine phenocrysts present in the rocks.

Mordenite is much less abundant than clinoptilolite, occurring randomly and almost exclusively in 

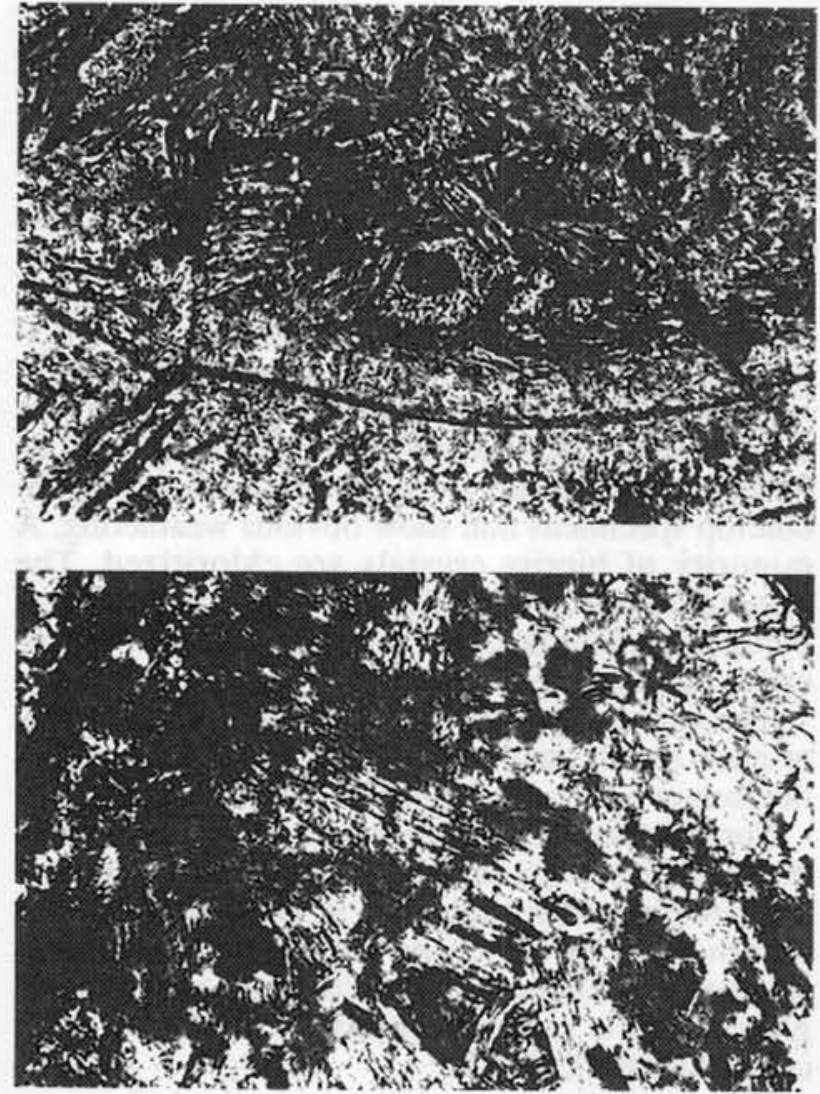

Fig. 5 a \& b.-Clinoptilolite prismatic crystals replacing glass shards and filling pore spaces (a: magnification X16, non-polarized light, b: magnification X25, non-polarized light).

the Petrota-Paleochorafa outcrops, as a minor or major constituent (table 1). In addition, mordenite is present in Pentalofos tuffs only as a joint coating, a feature that is also common in the Petrota-Paleochorafa tuffs (Kirov et al., 1990).

Clinoptilolite crystals occur abundantly in the porous pumice tuff of Palestra, forming tabular and or prismatic assemblages, hosted in the vesicular glass shards (figs. $5 \mathrm{a} \& \mathrm{~b}$ ). By contrast, clinoptilolite in the fine-grained layers of the Petrota and the Pentalofos tuff mainly occurs replacing glass shards, whereas euhedral or subhedral zeolite crystals are smaller and rarely developed (figs. $6 \mathrm{a} \&$ b).

The lithic clasts include mica-schist, quartzite, gneiss and lava. Lithic clasts are present at all the localities, but generally the biggest blocks occur near to the volcanic centre of Petrota. The tuffs at Pentalofos contain fewer detrital constituents and the clasts are only of small size. The metamorphic clasts are mostly made up of varying proportions of quartz and muscovite. The larger ones could be described as mica-schist, but some of the smaller ones are nearly all muscovite or nearly all quartz (Plate 1; E, F).
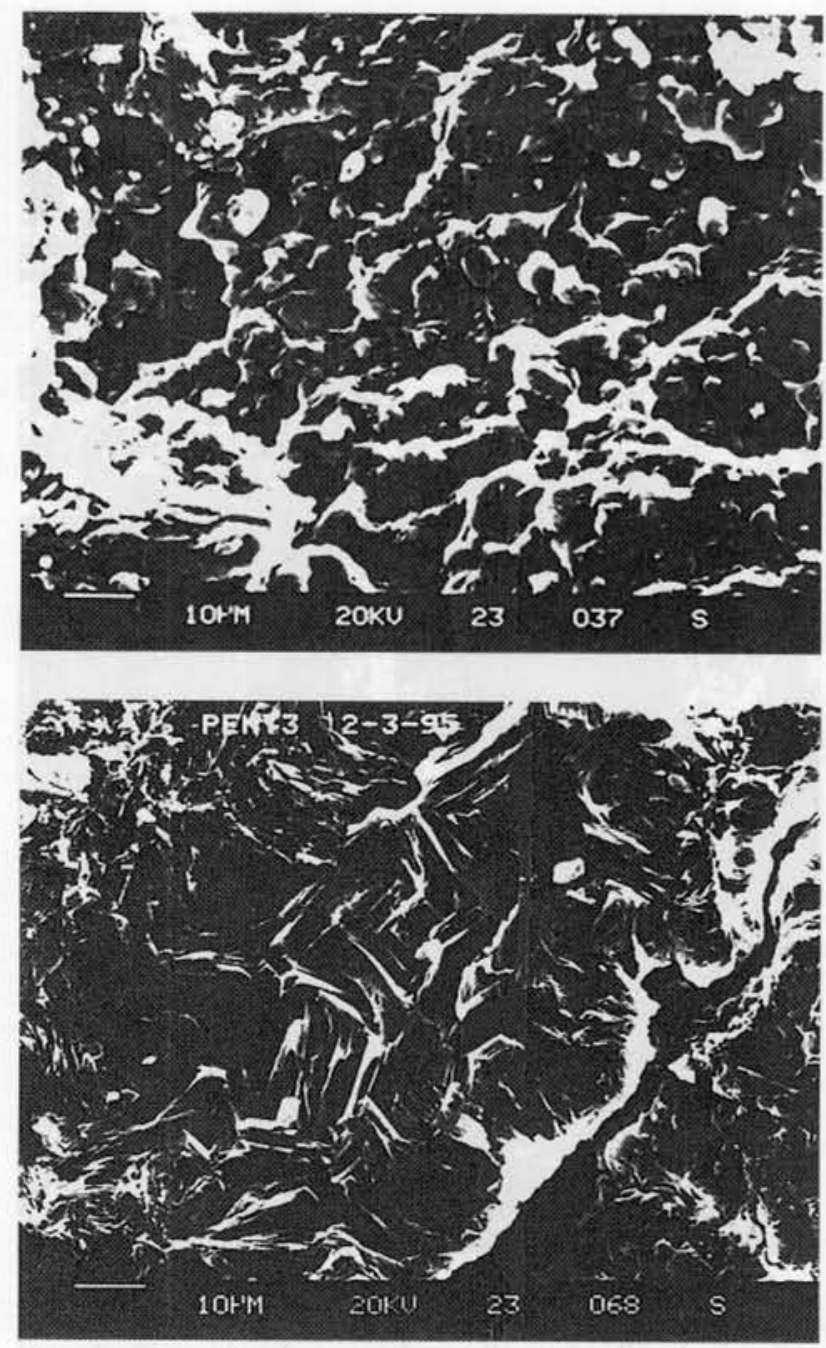

Fig. 6 a \& b.-Subhedral clinoptilolite crystals as they are shown by SEM analysis. Petrota-Paleochorafa tuffs $6 a$, Pentalofos quarry tuffs $6 b$ ).

A few larger clasts are made up only of quartz with a granoblastic texture and could be described as quartzite. A minority of the schist clasts contain biotite, indicating that the biotite in the rock may include both pyrogenic and detrital contributions. Many of the dispersed crystals in the tuff may be relicts from broken up lithic clasts; this is particularly true of muscovite (which never occurs as a primary mineral in volcanic rocks) and epidote, which is present in very small amounts.

The fine-grained tuffs show the same features as the coarser grained tuffs. Typically a fine-grained tuff contains crystals up to $0.1 \mathrm{~mm}$ and (devitrified) glass shards of the same size. Lithic clasts are not normally present in the fine tuffs but muscovite is often present, which could represent dispersed detrital material. 

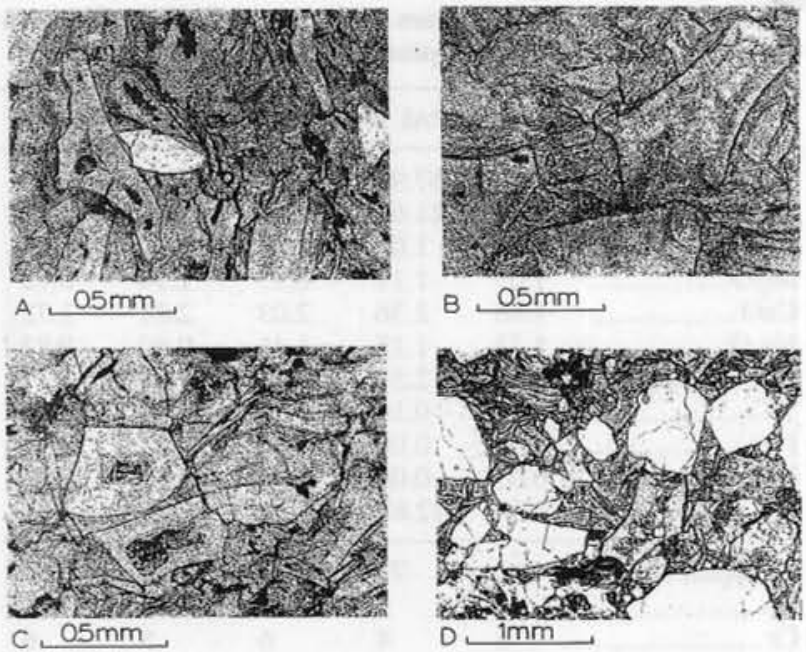

B $05 \mathrm{~mm}$.
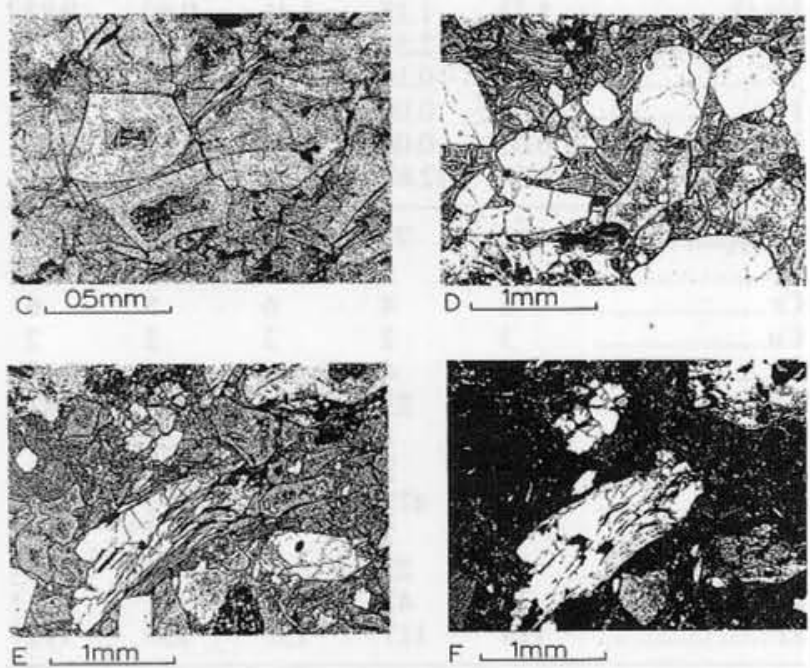

Plate 1.-Photomicrographs of thin sections of zeolitic tuffs (all the glass in these photographs is pseudomorphed by clinoptilolite): (A) A typical view showing abraded cuspate glass shards and detrital or pyrogenic grains of quartz and muscovite in a matrix of fine-grained glass particles. (B) Glass particles with concave margins (bubble walls) and rounded terminations in a matrix of fine-grained glass. (C) Rounded glass particles in a matrix of finer-grained glass; an elongated flake of detrital muscovite is visible in upper centre. (D) Detrital and pyrogenic quartz, feldspar and muscovite alongside glass shards of similar particle size. (E) A large clast of quartz-mica-schist (centre) in a matrix of glass fragments, detrital grains and fine-grained ground mass. Small crystals of garnet (high relief) are visible in a metamorphic clast at upper right. (F) Same view as E but between crossed polars, the low first order grey and fine grain size of the zeolitized groundmass contrast with the coarser grain size of the metamorphic clasts. Localities are Palestra (A, C) and Pentalofos (B, D, E, F). Photographs taken in planepolarized light, except $\mathrm{F}$.

Sedimentary re-working of the tuffs is indicated by two petrographic features of the devitirfied glassy particles (in addition to their admixture with non-volcanic detrital grains and lithic clasts). These are rounding and sorting. The cuspate terminations of the bubble-wall shards are not sharp or stretched out, but have been rounded, i.e. abraded, in a way that could not be achieved simply by extreme vesiculation (see Plate $1 ;$ C). On the hand specimen or outcrop scale, sorting is shown by the repeated interbedding of fine and coarse-grained tuff (turvidites) with sharply defined bedding planes that can not be matched in recent ash-fall or ash-flow deposits. In thin section, sorting is seen as a moderately uniform particle size of glass particles where the rock was mainly vitreous (Plate $1 ; \mathrm{C}$ ), and as roughly equal particle size of vitric and non-vitric grains where detrital or pyrogenic crystals are present (Plate 1; D). It can be seen from Plate 1; $\mathrm{C}$ that the extended cusps that would be present in bubble-wall shards of a newly fragmended pumiceous glass have been rounded off, giving the rock the texture of an immature glass sand.

Zeolitization post-dates the sedimentary reworking because the clinoptilolite laths which have grown in the glass shards are perpendicular to the margins of the shards, and do not cross the margins at all.

\section{Borehole samples}

Boreholes were drilled by the Silver and Barytes mining company at three sites in Pentalofos in an area $150 \times 100 \mathrm{~m}$, one site in Palestra, and one site in Petrota-Pelaochorafa (fig. 1). All five drill holes, Pen G1, G2 \& G3, Pall and Pet1, at these sites cut almost all the tuffaceous succession and finished by reaching the metamorphic basement.

Quantitative measurements of the mineralogical variation were carried out by X-ray diffraction on a total of 122 samples from two of the boreholes (Pen G2 and Pet G1). The Petrota G1 borehole core was divided into 66 sections each 1-2 m long for XRD measurement, and table 1 shows the results averaged over 3 main intervals. The Pentalofos G2 borehole core was divided into 56 sections each approximately $1 \mathrm{~m}$ long, and table 2 shows the results averaged over 2 main intervals.

The Petrota-Paleochorafa borehole samples show high zeolite content, comparing with the other boreholes samples, rising to over $65 \%$ throughout the top $40 \mathrm{~m}$ of the borehole. Approximately $15-20 \%$ of the rock in this borehole consists of primary minerals, including both detrital and pyrogenic components. Most of the feldspar and a proportion of the quartz and the mica (biotite) are pyrogenic, i.e. they represent phenocrysts present in the volcanic glass at the time of eruption. The remainder of the quartz and another part of the mica (muscovite) are detrital, since it was observed that quartz-muscovite schist fragments are the most common type of non-volcanic material included in the tuffs. At Petrota the metamorphic component makes up a relatively small proportion of the tuffs. The principal secondary minerals in the tuff at Petrota are zeolite and cristobalite. The amount of cristobalite is between 10 and $16 \%$, and there is a weak negative correlation between the amounts of zeolite and cristobalite. The crystalline constituents of the tuff 
Table 2a.-Chemical analyses of zeolitic tuffs from Pentalofos quarry.

\begin{tabular}{|c|c|c|c|c|c|c|c|}
\hline & PEN 2 & iv & & & & & \\
\hline $\mathrm{SiO}_{2} \ldots \ldots \ldots \ldots$ & 70.57 & 66.92 & 66.81 & 66.61 & 67.23 & 72.13 & 69.21 \\
\hline $\mathrm{Al}_{2} \mathrm{O}_{3} \ldots \ldots \ldots \ldots$ & 11.74 & 11.69 & 11.42 & 11.96 & 11.30 & 11.80 & 12.43 \\
\hline $\mathrm{Fe}_{2} \mathrm{O}_{3} \ldots \ldots \ldots$ & 1.36 & 1.09 & 1.08 & 1.25 & 0.99 & 2.24 & 1.31 \\
\hline $\mathrm{MgO}$ & 0.91 & 1.03 & 1.12 & 1.15 & 1.17 & 1.05 & 0.98 \\
\hline $\mathrm{CaO} \ldots \ldots \ldots \ldots . . . .$. & 1.97 & 2.98 & 3.34 & 3.27 & 3.45 & 1.60 & 2.74 \\
\hline $\mathrm{Na}_{2} \mathrm{O} \ldots \ldots \ldots \ldots$ & 0.33 & 0.71 & 0.63 & 0.96 & 0.55 & 0.83 & 1.03 \\
\hline $\mathrm{K}_{2} \mathrm{O}$ & 3.61 & 1.48 & 1.33 & 1.62 & 1.37 & 4.15 & 2.97 \\
\hline $\mathrm{TiO}_{2} \ldots \ldots \ldots \ldots \ldots$ & 0.17 & 0.15 & 0.15 & 0.18 & 0.16 & 0.39 & 0.26 \\
\hline $\mathrm{P}_{2} \mathrm{O}_{5} \ldots \ldots \ldots \ldots \ldots$ & 0.05 & 0.06 & 0.06 & 0.07 & 0.06 & 0.09 & 0.06 \\
\hline $\mathrm{MnO}$ & 0.02 & 0.02 & 0.02 & 0.02 & 0.02 & 0.01 & 0.01 \\
\hline Ign. Loss.......... & 9.63 & 12.78 & 13.74 & 13.06 & 14.08 & 6.42 & 9.07 \\
\hline $\mathrm{Ba}(\mathrm{ppm}) \ldots \ldots$. & 73 & 121 & 69 & 142 & 90 & 488 & 464 \\
\hline Со...................... & 5 & 5 & 5 & 5 & 4 & 6 & 6 \\
\hline $\mathrm{Cr}$ & 23 & 11 & 11 & 12 & 9 & 50 & 41 \\
\hline $\mathrm{Cu}$ & 6 & 3 & 3 & 3 & 3 & 11 & 6 \\
\hline Li ....................... & 12 & 9 & 5 & 6 & 5 & 17 & 10 \\
\hline $\mathrm{Nb}$ & 22 & 22 & 23 & 23 & 23 & 13 & 19 \\
\hline $\mathrm{Ni}, \ldots \ldots \ldots \ldots \ldots \ldots$ & 9 & 3 & 1 & 3 & 3 & 9 & 9 \\
\hline $\mathrm{Sc}$ & 3 & 3 & 3 & 3 & 3 & 8 & 7 \\
\hline $\operatorname{Sr} \ldots \ldots \ldots \ldots \ldots \ldots$ & 1144 & 1964 & 2010 & 2238 & 1914 & 1244 & 1497 \\
\hline V & 26 & 13 & 11 & 14 & 11 & 89 & 40 \\
\hline Y .................... & 25 & 20 & 23 & 32 & 24 & 24 & 23 \\
\hline $\mathrm{Zn} \ldots \ldots \ldots \ldots \ldots$ & 44 & 39 & 37 & 35 & 43 & 33 & 39 \\
\hline $\mathrm{Zr} \ldots \ldots \ldots \ldots \ldots$ & 100 & 73 & 102 & 130 & 141 & 173 & 115 \\
\hline La ........................ & 35 & 30 & 28 & 35 & 27 & 35 & 38 \\
\hline $\mathrm{Ce}$ & 62 & 57 & 49 & 60 & 45 & 53 & 66 \\
\hline $\mathrm{Nd} . . . \ldots \ldots \ldots \ldots . . . . . . . .$. & 19 & 19 & 12 & 16 & 11 & 18 & 18 \\
\hline $\mathrm{Sm}$ & 4.7 & 4.4 & 1.9 & 2.6 & 1.8 & 4.3 & 3.3 \\
\hline $\mathrm{Eu}$ & 0.4 & 0.4 & 0.2 & 0.3 & 0.2 & 0.7 & 0.4 \\
\hline Dy $\ldots \ldots \ldots \ldots \ldots \ldots$ & 3.0 & 2.7 & 1.9 & 2.7 & 1.8 & 2.9 & 2.4 \\
\hline Yb..................... & 2.5 & 2.1 & 2.3 & 3.2 & 2.4 & 1.6 & 1.8 \\
\hline
\end{tabular}

amount to approximately $85-95 \%$ of the total rock, the remainder being non-crystalline, i.e. an amorphous residue from the alteration of the original volcanic glass. No unaltered glass was observed.

The Pentalofos borehole samples are broadly similar to those from Petrota, but show slightly different proportions of the main constituents. There is a higher proportion of detrital minerals, indicated by higher quartz and mica, which is mainly muscovite. There is a slightly lower proportion of pyrogenic minerals, indicated by lower feldspar. Unlike at Petrota, the tuffs from Pentalofos show a clear positive correlation between the two main secondary minerals, zeolite and cristobalite. There is a much higher proportion of amorphous material in the Pentalofos tuffs than at Petrota.

\section{Quarry samples}

Channel sampling was performed in the Pentalofos, Twin Hills, Palestra and Petrota quarries
Table $2 b$.- Chemical analyses of zeolitic tuffs from Palestra quarry.

\begin{tabular}{|c|c|c|c|c|c|}
\hline & PAL 1 & PAL 2 & PAL 3 & PAL 4 & PAL 5 \\
\hline $\mathrm{SiO}_{2} \ldots \ldots \ldots \ldots$ & 68.89 & 67.94 & 69.89 & 67.46 & 68.19 \\
\hline $\mathrm{Al}_{2} \mathrm{O}_{3} \ldots \ldots \ldots \ldots \ldots$ & 12.40 & 11.67 & 12.27 & 11.33 & 11.80 \\
\hline $\mathrm{Fe}_{2} \mathrm{O}_{3} \ldots \ldots$ & 1.14 & 1.09 & 1.05 & 0.97 & 1.03 \\
\hline $\mathrm{MgO}$ & 1.03 & 1.11 & 0.93 & 1.14 & 0.98 \\
\hline $\mathrm{CaO}$ & 1.88 & 2.36 & 2.03 & 2.81 & 2.72 \\
\hline $\mathrm{Na}_{2} \mathrm{O}$ & 1.73 & 1.15 & 1.46 & 0.60 & 0.82 \\
\hline $\mathrm{K}_{2} \mathrm{O}$ & 3.67 & 2.59 & 3.04 & 1.95 & 2.31 \\
\hline $\mathrm{TiO}_{2} \ldots \ldots \ldots \ldots \ldots$ & 0.18 & 0.16 & 0.16 & 0.14 & 0.14 \\
\hline $\mathrm{P}_{2} \mathrm{O}_{5} \ldots \ldots \ldots \ldots \ldots$ & 0.04 & 0.05 & 0.05 & 0.05 & 0.05 \\
\hline MnO & 0.03 & 0.08 & 0.03 & 0.02 & 0.03 \\
\hline Ign. Loss .................. & 10.30 & 12.67 & 10.78 & 13.86 & 11.84 \\
\hline $\mathrm{Ba}(\mathrm{ppm}) \ldots \ldots \ldots$ & 91 & 72 & 96 & 49 & 69 \\
\hline Со...................... & 6 & 5 & 6 & 4 & 6 \\
\hline $\mathrm{Cr}$ & 6 & 4 & 6 & 5 & 6 \\
\hline $\mathrm{Cu}$ & 3 & 2 & 2 & 2 & 2 \\
\hline $\mathrm{Li}$ & 4 & 4 & 6 & 6 & 7 \\
\hline $\mathrm{Nb}$ & 22 & 23 & 21 & 24 & 21 \\
\hline $\mathrm{Ni}$ & 0 & 1 & 1 & 1 & 2 \\
\hline $\mathrm{Sc}$ & 3 & 2 & 3 & 2 & 3 \\
\hline Sr......................... & 199 & 473 & 717 & 1072 & 1321 \\
\hline $\mathrm{V}$ & 9 & 7 & 9 & 7 & 10 \\
\hline Y & 18 & 23 & 48 & 17 & 18 \\
\hline $\mathrm{Zn}$ & 34 & 42 & 32 & 31 & 31 \\
\hline $\mathrm{Zr}$ & 114 & 117 & 132 & 133 & 112 \\
\hline La ............................. & 35 & 45 & 49 & 34 & 34 \\
\hline $\mathrm{Ce}$ & 48 & 61 & 122 & 50 & 47 \\
\hline $\mathrm{Nd}$ & 12 & 18 & 21 & 16 & 17 \\
\hline $\mathrm{Sm}$ & 2.0 & 3.2 & 4.3 & 3.3 & 3.8 \\
\hline Eu........................ & 0.2 & 0.2 & 0.3 & 0.3 & 0.3 \\
\hline 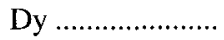 & 1.6 & 2.6 & 4.5 & 2.2 & 2.3 \\
\hline Yb & 1.9 & 2.0 & 3.7 & 1.9 & 1.9 \\
\hline
\end{tabular}

(table 1). In Pentalofos sampling was performed in an active quarry, where 43 samples were obtained, representing the uppermost $43 \mathrm{~m}$ of the tuff. In these samples, the uppermost tuff layers of nine metres thick have a greyish colour, containing more detrital components, such as micas, feldspars and guartz. Smectite is present in some intervals, whereas non-zeolitized volcanic glass is present at that level (fig. 3). The next $23 \mathrm{~m}$ are very rich in clinoptilolite that is only accompanied by minor cristobalite and volcanic glass (table 3 ). This succession is more fine grained than the former, representing an ash flow deposit. The lowermost $11 \mathrm{~m}$ of the tuff are mainly represented by porous, pumice-like material rich in detrital fragments, especially close to the basement.

The fine grained tuffs that constitute the middle of the section, totalling $23 \mathrm{~m}$ seem to be the richest in clinoptilolite of any zeolitic tuff that has been reported from Greece. Twin Hills and Palestra channel samples have similar X-ray mineralogy to those from Pentalofos quarry. They are mainly 
Table 2c.-Chemical analyses of lava (Pet 2) and zeolitic tuffs (Pet 1 \& Pet 4-16) from Petrota-Paleochorafa quarry.

\begin{tabular}{|c|c|c|c|c|c|c|c|c|c|}
\hline & Pet 2 & Pet 1 & Pet 4 & Pet 11 & Pet 12 & Pet $12 \mathrm{~A}$ & Pet 13 & Pet 15 & Pet 16 \\
\hline $\mathrm{SiO}_{2} \ldots \ldots \ldots \ldots \ldots$ & 79.15 & 68.76 & 69.81 & 67.31 & 68.90 & 69.41 & 67.40 & 69.37 & 65.98 \\
\hline $\mathrm{Al}_{2} \mathrm{O}_{3} \ldots \ldots \ldots \ldots \ldots$ & 11.08 & 12.11 & 11.80 & 12.79 & 12.23 & 11.54 & 12.15 & 12.02 & 12.33 \\
\hline $\mathrm{Fe}_{2} \mathrm{O}_{3} \ldots \ldots \ldots \ldots$ & 0.74 & 1.44 & 0.93 & 1.39 & 1.10 & 1.05 & 1.13 & 0.95 & 1.02 \\
\hline $\operatorname{MgO} \ldots \ldots \ldots \ldots \ldots \ldots$ & 0.10 & 0.77 & 0.70 & 0.80 & 0.61 & 0.89 & 0.90 & 0.78 & 0.96 \\
\hline $\mathrm{CaO}$ & 0.46 & 2.35 & 1.95 & 1.71 & 1.74 & 2.07 & 2.09 & 2.38 & 2.69 \\
\hline $\mathrm{Na}_{2} \mathrm{O} \ldots \ldots \ldots \ldots \ldots \ldots$ & 1.17 & 1.18 & 0.84 & 1.90 & 2.53 & 0.83 & 1.31 & 0.73 & 0.34 \\
\hline $\mathrm{K}_{2} \mathrm{O} \ldots \ldots \ldots \ldots \ldots \ldots$ & 5.78 & 4.00 & 3.96 & 3.96 & 3.74 & 3.99 & 3.41 & 3.88 & 2.94 \\
\hline $\mathrm{TiO}_{2} \ldots \ldots \ldots \ldots \ldots \ldots \ldots$ & 0.13 & 0.22 & 0.14 & 0.16 & 0.16 & 0.15 & 0.15 & 0.14 & 0.13 \\
\hline $\mathrm{P}_{2} \mathrm{O}_{5} \ldots \ldots \ldots \ldots \ldots \ldots$ & 0.03 & 0.05 & 0.04 & 0.04 & 0.04 & 0.04 & 0.04 & 0.04 & 0.05 \\
\hline $\mathrm{MnO}$ & 0.02 & 0.05 & 0.03 & 0.02 & 0.02 & 0.02 & 0.02 & 0.03 & 0.02 \\
\hline Ign. Loss.............. & 2.07 & 9.57 & 9.71 & 11.98 & 10.80 & 11.30 & 12.69 & 8.68 & 11.75 \\
\hline $\mathrm{Ba}(\mathrm{ppm}) \ldots \ldots \ldots \ldots$ & 446 & 124 & 74 & 90 & 126 & 62 & 85 & 82 & 33 \\
\hline Сo ................... & 2 & 7 & 5 & 5 & 5 & 3 & 6 & 6 & 4 \\
\hline $\mathrm{Cr}$ & 5 & 7 & 3 & 4 & 3 & 5 & 3 & 3 & 3 \\
\hline $\mathrm{Cu} \ldots \ldots \ldots \ldots \ldots \ldots \ldots$ & 3 & 3 & 2 & 3 & 1 & 2 & 4 & 1 & 2 \\
\hline $\mathrm{Li}$ & 9 & 8 & 8 & 8 & 5 & 9 & 7 & 6 & 8 \\
\hline $\mathrm{Nb}$ & 19 & 23 & 21 & 26 & 22 & 26 & 24 & 21 & 25 \\
\hline $\mathrm{Ni}$ & 4 & 2 & 2 & 4 & 0 & 1 & 1 & 0 & 0 \\
\hline Sc ................................. & 2 & 3 & 2 & 3 & 2 & 2 & 2 & 2 & 2 \\
\hline $\mathrm{Sr} \ldots \ldots \ldots \ldots \ldots \ldots \ldots$ & $6 \overline{5}$ & 77 & 51 & 76 & 80 & 58 & 66 & 55 & 55 \\
\hline 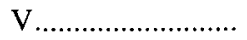 & 5 & 11 & 5 & 7 & 5 & 7 & 5 & 5 & 5 \\
\hline Y ........................ & 11 & 14 & 19 & 27 & 24 & 25 & 21 & 21 & 26 \\
\hline Zn ........................ & 15 & 38 & 36 & 60 & 41 & 43 & 45 & 36 & 45 \\
\hline $\mathrm{Zr} \ldots \ldots \ldots \ldots \ldots \ldots \ldots \ldots \ldots \ldots \ldots$ & 105 & 136 & 121 & 131 & 124 & 120 & 122 & 118 & 130 \\
\hline La ........................ & 26 & 29 & 28 & 45 & 38 & 39 & 28 & 33 & 40 \\
\hline $\mathrm{Ce}$ & 50 & 49 & 47 & 72 & 59 & 62 & 47 & 52 & 65 \\
\hline 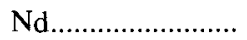 & 17 & 12 & 15 & 18 & 14 & 15 & 11 & 14 & 20 \\
\hline $\mathrm{Sm}$ & 3.5 & 3.2 & 4.3 & 3.3 & 2.7 & 3.5 & 2.6 & 3.6 & 5.2 \\
\hline Eu ......................... & 0.5 & 0.3 & 0.3 & 0.2 & 0.2 & 0.2 & 0.2 & 0.3 & 0.3 \\
\hline Dy,.......................... & 1.6 & 1.7 & 2.3 & 2.6 & 2.1 & 2.6 & 2.0 & 2.2 & 3.0 \\
\hline 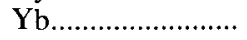 & 1.0 & 1.4 & 2.0 & 2.3 & 2.3 & 2.2 & 2.0 & 1.9 & 2.4 \\
\hline
\end{tabular}

composed of clinoptilolite with minor cristobalite, potassium and socium-feldspars. The coarse-grained layers contain more pyrogenic and detrital components, such as feldspars, quartz and mafic minerals.

Interestingly, Pentalofos quarry that is $200 \mathrm{~m}$ south of the 3 boreholes show higher percentage of zeolite comparing with the borehole samples.

In general, field and laboratory measurements on surface and boreholes samples in all outcrops of the area, show an increase of the non-zeolitic material in the tuff samples, from south-east (Pentalofos quarry) towards to the north-west (Petrota Guardhouse), owed to the frequent presence of detrital horizons or constituents in each particular tuff layer.

Besides Pentalofos quarry, smectite is present in small amounts (up to $7 \%$ ) and in near-surface samples from Petrota borehole, but it is absent in the rest of the borehole sections, and is presumed to be a surface weathering product unrelated to zeolitization.

\section{Geochemical data}

Table 2 shows the chemical composition of the freshest available lava from Petrota, and zeolitic tuffs from the same locality. The lava (analysis 2 ) lies outside the normal range of magma compositions, having $\mathrm{SiO}_{2}$ too high for a rock with no primary quartz, and $\mathrm{a} \mathrm{K}_{2} \mathrm{O} / \mathrm{Na}_{2} \mathrm{O}$ ratio higher than any common lava type. The phenocrysts are completely fresh, e.g. the plagioclase is very clear and has wellpreserved normal and oscillatory zoning and the biotite is free of chloritization or any other obvious secondary alteration. However, the former glassy groundmass is clearly enriched in $\mathrm{K}_{2} \mathrm{O}$ and $\mathrm{SiO}_{2}$, represented by $\mathrm{K}$-feldspar and cristobalite. Presumably this type of alteration was a precursor to the zeolitization which has affected the vitric tuffs.

The compositions of zeolitic tuffs from the three main outcrops are shown in tables $2 a, b$ \& , and 3 . In general, all the compositions are similar to one another, and show the high $\mathrm{SiO}_{2}$ (even higher on a $\mathrm{H}_{2} \mathrm{O}$-free basis) and low $\mathrm{Fe}, \mathrm{Ti}, \mathrm{Mg}$ expected of fel- 


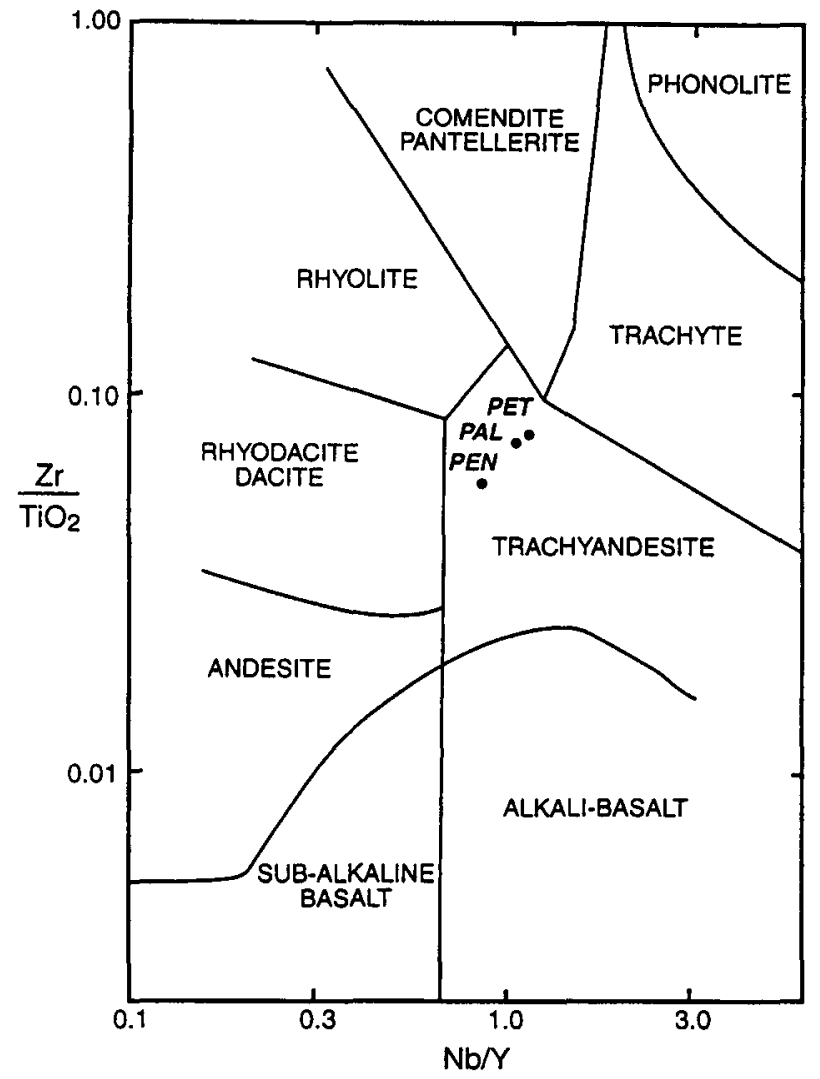

Fig. 7.-Immobile element ratios.

sic volcanic rocks. At each of the localities the tuffs with the highest zeolite contents are characterized by low $\mathrm{SiO}_{2}$ and high ignition oss. A high zeolite content is also correlated with high $\mathrm{CaO}$ and low $\mathrm{K}_{2} \mathrm{O}$ in the rock as a whole.

Figure 7 shows the relations between the immobile element ratios $\mathrm{Zr} / \mathrm{Ti}$ and $\mathrm{Nb} / \mathrm{Y}$, which are widely used for magma characterisation. On this plot the compositions of the tuffs from the three outcrops plot close together, and all lie at the silicic end of the trachyandesite field, i.e. corresponding to an original magma of latite or quartz-latite composition. This is consistent with what can be seen of the relict pyrogenic minerals, i.e. plagioclase, alkali feldspar and biotite are abundant, but quartz occurs either in small amounts or is absent.

The greatest variation in major element concentrations is in the exchangeable cations $\mathrm{Mg}^{2+}, \mathrm{Ca}^{2+}$, $\mathrm{Na}^{+}$, and $\mathrm{K}^{+}$(table 4). Compared with the other two deposits, the rocks from Petrota are lower in $\mathrm{MgO}$ and $\mathrm{CaO}$ and higher in $\mathrm{Na}_{2} \mathrm{O}$ and $\mathrm{K}_{2} \mathrm{O}$. In this respect they are closest in composition to the probable original composition of a felsic magma, although even so the $\mathrm{Na}_{2} \mathrm{O}$ content is too low for a fresh rock. The rocks from Pentalofos are higher in $\mathrm{MgO}$ and $\mathrm{CaO}$ and lower in $\mathrm{Na}_{2} \mathrm{O}$ and $\mathrm{K}_{2} \mathrm{O}$ than the other deposits. These differences suggest cation exchange by $\mathrm{Ca}-\mathrm{Mg}$-bearing groundwater, possibly related to the presence of limestone in the Paleogene succession overlying the zeolitic beds. Unpublished electron microprobe analyses of the zeolite in these rocks show that although it is clinoptilolite (i.e. with high $\mathrm{Si} / \mathrm{Al}$ ratios), $\mathrm{Ca}$ is the predominant exchangeable cation (Prof. A. Kassoli-Fournaraki, personal comm.).

The $\mathrm{Na}_{2} \mathrm{O}$ content of all the zeolitized rocks is very low, i.e. much lower than that of any felsic lava type, and is not correlated with either $\mathrm{CaO}$ or $\mathrm{K}_{2} \mathrm{O}$. It appears that $\mathrm{Na}_{2} \mathrm{O}$ has been strongly depleted by the zeolitization process, which has two implications: (1) that zeolitization took place in an open hydrological system; and (2) the water in which the original ashes were deposited was not seawater.

The trace elements fall into two groups. The high field strenght elements are relatively immobile during hydrothermal alteration and have concentrations appropriate to felsic volcanic rocks as has been mentioned above, whereas the univalent and divalent elements show large variations attributable to cation exchange. This is particularly apparent in the distribution of $\mathrm{Sr}$, which shows a similar pattern of distribution to $\mathrm{Ca}$ but far more extreme. In Pentalofos, $\mathrm{Ca}$ is higher than average and $\mathrm{Sr}$ is extremely high, whereas in Petrota $\mathrm{Ca}$ is lower than average and $\mathrm{Sr}$ is extremely low. This variation could possibly be related to cation exchange with groundwater that has or has not previously interacted with limestone. In view of the relative selectivity of clinoptilolite for various cations, i.e. $\mathrm{K}>\mathrm{Ba}>\mathrm{Na}>\mathrm{Sr}$ $>\mathrm{Ca}$ (Tsitsishvili et al., 1992) it is surprising that strontium is so strongly enriched in the Pentalofos tuffs, when potassium and barium are within the normal range for igneous rocks. This suggests that the tuffs have interacted with strontium-rich waters at some time in their history.

There are two possible sources of strontium-rich water that may be considered: either the tuffs were deposited in hypersaline water of marine origin (strontium is the most abundant cation in seawater after sodium, magnesium, calcium and potassium); or they have interacted with groundwater derived from limestone undergoing aragonite to calcite transformation (strontium can substitute for calcium in aragonite but not in calcite or dolomite). A hypersaline environment of deposition is very unlikely because of the very low sodium content of the zeolitic rocks, and reaction with strontium-rich groundwater is much more probable. This is confirmed by the distribution of $\mathrm{Sr}$ and other exchangeable cations in the borehole samples (table 7). There 
Table 3.-Average compositions of the zeolitic tuffs.

\begin{tabular}{|c|c|c|c|}
\hline & $\begin{array}{c}\text { Petrota } \\
\text { Paleochorafa }\end{array}$ & Palestra & Pentalofos \\
\hline $\mathrm{SiO}_{2}$ & 68.37 & 68.47 & 68.50 \\
\hline 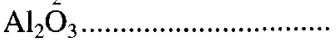 & 12.12 & 11.89 & 11.76 \\
\hline $\mathrm{Fe}_{2} \mathrm{O}_{3} \ldots \ldots \ldots \ldots \ldots \ldots \ldots \ldots$ & 1.13 & 1.06 & 1.33 \\
\hline $\mathrm{MgO}$ & 0.80 & 1.04 & 1.06 \\
\hline $\mathrm{CaO}$ & 2.12 & 2.36 & 2.76 \\
\hline $\mathrm{Na}_{2} \mathrm{O}$ & 1.21 & 1.15 & 0.72 \\
\hline $\mathrm{K}_{2} \mathrm{O}$ & 3.74 & 2.71 & 2.36 \\
\hline 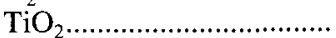 & 0.16 & 0.16 & 0.21 \\
\hline $\mathrm{P}_{2} \mathrm{O}_{5} \ldots \ldots \ldots \ldots \ldots \ldots \ldots \ldots$ & 0.04 & 0.05 & 0.06 \\
\hline $\mathrm{MnO}$ & 0.03 & 0.04 & 0.02 \\
\hline 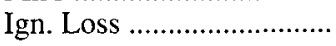 & 10.81 & 11.89 & 11.25 \\
\hline $\mathrm{Sr}(\mathrm{ppm})$ & 65 & 756 & 1716 \\
\hline
\end{tabular}

is a general trend for calcium, magnesium and strontium to increase towards the top of the succession and for potassium and sodium to increase towards the bottom. In effect, the entire zeolitic tuff deposit has acted as a gigantic ion exchange column.

\section{Origin of the zeolites}

All the quarry exposures are small, and in most of the intervening areas the tuffs are covered by younger deposits. Additionally, the continuity of the deposits is interrupted by faulting. Subject to these limitations, our interpretation on the nature of the deposits is as follows.

The tuffs are not air-fall deposits because beds do not have a uniform thickness over a distance of more than a few metres, and many of them are much too coarse. They are not pyroclastic surge deposits because they do not show the dune-like structures characteristic of surges and they are too well-bedded with many sharply defined bedding planes. They are not pyroclastic flow deposits, also because they are too well-bedded, and in addition there is no welding and only occasional flattening of glass particles (although these features are not present in all ash flows).

The deposits are interpreted as ash that has been re-deposited by water. Bedding and turbiditic structures represented by fine-grained to coarser, pumice tuff alternations are well developed, and low-angle cross-bedding is present in all deposits studied. Channel filling structures are present in Palestra quarry. Non-volcanic detritus is common, especially at Pentalofos and especially in the lower part of the tuff succession. The predominant and most easily recognisable non-volcanic clasts in all five outcrops are those of metamorphic origin, which include
Table 4.-Exchangeable cations in borehole samples from different depths.

\begin{tabular}{lcccccc}
\hline & $\begin{array}{c}\text { Depth } \\
(\mathrm{m})\end{array}$ & $\begin{array}{c}\mathrm{K}_{2} \mathrm{O} \\
(\%)\end{array}$ & $\begin{array}{c}\mathrm{Na}_{2} \mathrm{O} \\
(\%)\end{array}$ & $\begin{array}{c}\mathrm{CaO} \\
(\%)\end{array}$ & $\begin{array}{c}\mathrm{MgO} \\
(\%)\end{array}$ & $\begin{array}{c}\mathrm{Sr} \\
(\mathrm{ppm})\end{array}$ \\
\hline Petrota- & 2 & 2.31 & 1.17 & 2.38 & 0.97 & 823 \\
Paleochorafa $G 1$ & 40 & 2.65 & 0.60 & 2.41 & 0.86 & 209 \\
& 81 & 2.98 & 1.46 & 1.55 & 0.78 & 66 \\
& 97 & 3.73 & 1.43 & 1.19 & 0.76 & 66 \\
\hline Pentalofos G2 & 14 & 2.23 & 0.75 & 2.68 & 1.00 & 855 \\
& 34 & 3.09 & 0.68 & 2.49 & 0.98 & 399 \\
& 54 & 3.20 & 1.45 & 1.96 & 0.84 & 193 \\
\hline
\end{tabular}

minerals characteristic of both low and high metamorphic grades, e.g. chlorite and garnet, suggesting derivation from a large or mixed source area. A characteristic non-volcanic mineral is muscovite, which occurs dispersed in the tuffs as well as being a constituent of metamorphic clasts. There are also abundant large fragments of lava in all the tuffs of the Petrota outcrop, whereas they are absent from the southernmost tuff outcrops of Palestra, Twin Hill and Pentalofos.

The zeolitic tuffs of this area originated as epiclastic volcanic sediments, i.e. they were transported by water from the source of the eruption. They are partially mixed with non-volcanic detritus, but the volcanic component of the tuffs consisted predominantly (c. $90 \%$ ) of glassy particles at the time of deposition. This glass has been altered to zeolites, whilst the associated pyrogenic crystals remain almost unaltered.

The tuff laminae in the marlstone overlying the main tuff formation and the grey uppermost tuff itself have only partially been transformed to zeolite and cristobalite. Going stratigraphically downwards, the fresh glass has been gradually transformed to clinoptilolite plus minor cristobalite.

This gradual and stratigraphy-related alteration of volcanic glass is characteristic of the action of meteoric waters in an open hydrologic system. It may be possible to determine the time of original zeolitization. The tuffaceous formation was uplifted during the late Eocene, as shown by the unconformity between it and the overlying Upper Eocene reefal limestone that discordantly covers all the older formations. Acid to intermediate tuffs that were erupted in a later stage (Oligocene) near Neon Chimonion (30 km SE of Pentalofos) are not zeolitized. Their original glassy material is partially transformed to smectite and opal but not zeolites. This is evidence that the zeolitization process took place between the late Eocene and Oligocene. At that time the older tuffs were uplifted and affected by circulating meteoric waters in an open hydrologic system. The solutions were rich in silica, as it is 
resulted by the presence of silicified woods in the clastic series of the Eocene-Oligocene rocks (Andronopoulos, 1977, Prof. E. Velitzelos, 1996 person. comm.).

Subsequent modification of the zeolitized tuffs by cation exchange with circulating groundwater could have taken place at any time up to the present day.

Groundwater is still active now, as all the pyroclastic rocks studied here are intensely fractured and have relatively high porosity. The lower part of the tuff succession is currently water-saturated, as shown by several water tables that were met during the drilling project in the area. The $\mathrm{pH}$ measured in the water table at $13.5 \mathrm{~m}$ depth in the PenG2 borehole of the Pentalofos area is between 7.5 to 8.0. Within the fractures of the tuff, groundwater has deposited brownish/whitish films of secondary minerals, such as smectite and calcite. Smectite could be formed in expense of clinoptilolite, as has been described from other clinoptilolite deposits (Stamatakis, 1989). The potential formation of smectite before and after clinoptilolite (Hay, 1977; Stamatakis, 1989) is evidence that zeolites can easily be transformed to other authigenic minerals at the same diagenetic and post-diagenetic conditions.

Porosity/Permeability of the tuff was a significant factor in zeolitization, because the massive volcanic bombs that are present in a zeolite-rich ground mass in the Petrota outcrop, do not show any degree of zeolitization.

Heat flow does not seem to have played an important role, because the volcanic glass of the lavas adjacent to the Petrota deposit is not zeolitized ( + low porosity/permeability). In addition, the only zeolite found in the tuffs apart from clinoptilolite is mordenite, which occurs in trace amounts in Petrota areas, which are the outcrops closest to the occurrence of lavas. There is no «zoning» of high-temperature zeolites near the contact of lava with the tuff.

However as mordenite is usually formed at higher temperatures than clinoptilolite (Sheppard, Gude \& Fitzpatrick, 1988; Kirov et al., 1990), it is suggested that in the Petrota area the nearby lava extrusions are partially responsible for the local formation of mordenite, which is absent from the other deposits that are further away from the volcanic centres.

Mineralogical investigacion of tuffs and lavas on the Bulgarian zeolitic tuffs, afected by a «geo-autoclave system», westernmost of Pentalofos-Petrota, has shown the presence of mordenite-rich tuffs surrounding rhyolitic lavas, whereas clinoptilolite rich tuffs occur in more distal places, surrounding mordenite-rich tuffs (Tzvetanov et al., 1983; Kirov et al., 1990).

The original tuffs were probably deposited in isolated depressions formed by severe tectonic activity that has created an intensely faulted basement (Noussinanos, 1991). On the other hand, late tectonic activity that has affected not only the basement but also the tuffs, and has cut any long zeolitic tuff deposit to small ones.

\section{Commercial importance}

The most promising zeolite deposits for mine development in the Petrota-Pentalofos area those of Pentalofos, Palestra and Petrota-Paleochorafa with total proven and probable reserves amounting to $42,700,000$ tonnes of clinoptilolite-bearing tuffs.

Based on the results of exploration and specific chemical, physical and mineralogical analyses and tests, the Pentalofos fine-grained zeolitic tuff is the most important among all and can supply material that could be used in a wide range of application, including uses for animal feeding waste water cleaning, fish farming and as additive in cement.

Recently, mining by open-pit-method started in the southern part of the Pentalofos deposit. The fine-grained zeolitic tuff material is crushed, screened in various sizes and bagged in a treatment plant owned by Silver \& Baryte Ores Mining Company S.A., Athens, Greece. Most of the extracted material is for swine nutrition and fish-farming applications so far.

\section{ACKNOWLEDGEMENTS}

This study was partially funded by the EU under BriteEuram project no. BRE2-CT94-0954 «Development of Industrial and Environmental Uses of European Natural Zeolites". We are particularly grateful for the work of Chris Bonney as coordinator of this project. We are also indebted to Dr P. Karkanas, Ch. Vasilatos (for assistance in field work), Dr. K. Koskeridou (for paleontological analysis), to Simon Inglethorpe of the British Geological Survey for thermogravimetric measurements on the clinoptilolite-rich sample used as an XRD standard, and to Barbara Leila for asisstance with the XRD analyses. Dr. James Hein of te USGS (Menlo Park, California) is also acknowledged for his helping in SEM analysis.

Silver and Barytes personnel is also acknowledged, especially Th. Koutles for his assistance to field work and logging.

\section{References}

Andronopoulos, B. (1977). Geological study of Didymotichon-Pentalofos area, Orestias basin. Geol. and Geophy. Res., IGME, Athens, 17, 59 (in Greek).

Andronopoulos, B. (1978a). Geological map of Greece 1:50,000, sheet Ormenion, IGME publications, Athens, Greece. 
Andronopoulos, B. (1978b). Geological map of Greece 1:50,000, sheet Rizia, IGME publications, Athens, Greece.

Djurova E. and Aleksiev B. (1990). Zeolitic rocks related to the second acidic Paleogene volcanism to the east of the town of Kurdkali. Geologica Rodopica, 1, 202-217.

Eleftheriadis, G., Christofides, G., Mavroudchiev, B., Nedyalkov, R., Andreev, A., and Hristov, L. (1989). Tertiary volcanics from the east Rhodopes in Greece and Bulgaria. Geol. Rhodopica, 1, 202-217.

Hay, R. L. (1977). Geology of zeolites in sedimentary rocks. In: Mumpton, F. A. (ed.): Mineralogy and geology of natural zeolites. Reviews in Mineralogy, Mineral. Soc. Amer., 4, 43-51.

Kirov, G. N., Filippidis, A., Tsirambidis, A., Tzvetanov, R. G., and Kassoli-Fournaraki, A. (1990). Zeolite-bearing rocks in Petrota area (Eastern Rhodope Massif, Greece). Geol. Rodopica, 2, 500-511.

Kosiaris, G., Karandasi, S., and Grigoriadis, G. (1987). Zeolite occurrences in west Thrace, Unpubl. Report, IGMR, Athens, 30 pp.

Koutles, Th., Kassoli-Fournarakis, A.; Filippidis, A., and Tsirambides, A. (1995). Geology and geochemistry of the Eocene zeolite-bearing volcaniclastic sediments of Metaxades, Thrace, Grece, Estudios Geol., 51: 19-27.

Marandos, J., Kosiaris, G., Karantasi, S. and Grigoriadis, G. (1989). A study on zeolitic alteration of Tertiary pyroclastics from Metaxades area, Evros county, Greece. Bull. Geol. Soc. Greece, 23, 443-450.

Noussinanos, Th. (1991). Classification of hydrocarbon basins of NE Greece. Mineral Wealth, 73, 33-56.

Skarpelis, N., Economou, M., and Michael, K. (1987). Geology, petrology and polymetallic ore types in a
Tertiary volcanosedimentary terrain, Virini-PessaniDadia, West Thrace (northern Greece). Geol. Balcanica, 17, 31-41.

Stamatakis, M. G. (1989). Boron-bearing K-feldspar in volcanic ash and tuffite from Miocene lake deposits, Samos Island, Greece. Amer. Mineral., 74, 230-235.

Stamatakis, M. G., Hall, A., and Hein, J. R. (1996). The zeolite deposits of Greece. Mineralium Deposita, 31, 473-481.

Sheppard, R. A., Gude, A. J., and Fitzpatrick, J. J. (1988). Distribution, characterization and genesis of mordenite in Miocene silicic tuffs at Yucca Mountain, Nye County, Nevada. U.S. Geol. Surv. Bull., 1777, 22 pp.

Tsitsishvili, G. V., Andronikashvili, T. G., Kirov, G. N., and Filizova, L. D. (1992). Natural zeolites, Ellis Horwood, New York and London.

Tsolis-Katagas, P., and Katagas, C. (1990). Zeolitic diagenesis of Oligocene pyroclastic rocks of the Metaxades area, Thrace, Greece. Mineral. Magazine, 54, 95103.

Tzvetanov, R. G., Kirov, G. N., and Topolova, I. T. (1983). Zeolite mineralizations in the tuffs of the Malko Gradishte and Eferem volcanoes, Eastern Rhodopes. Ann. Univ. Sofia, Fac. Geol. Geogr. Livre 1, Geologie, 77, 71-77 (English abstract).

Yanev, Y., and Bardintzeff, J. M. (1997). Petrology, volcanology and metallogeny of Paleogene collision-related volcanism of the Eastern Rhodopes (Bulgaria). Terra Nova, 9, 1-8.

Recibido el 12 de enero de 1998. Aceptado el 4 de febrero de 1998. 